\title{
PERANCANGAN SISTEM INFORMASI FIXED ASSET APPLICATION PADA PT SUMBER ALFARIA TRIJAYA TBK
}

\author{
Puguh Laksono', Siti Khotijah², Ade Syahrul Ramdan ${ }^{3}$ \\ ${ }^{1,2,3}$ Universitas Indraprasta PGRI \\ Jl. Raya Tengah No. 80, Kel. Gedong, Kec. Pasar Rebo, Jakarta Timur 13760, Jakarta \\ 1camo493@gmail.com, ${ }^{2}$ sitik2805@gmail.com, ${ }^{3}$ as.ramdan13@gmail.com
}

\begin{abstract}
ABSTRAK
Penulis membuat sistem fixed asset application pada PT Sumber Alfaria Trijaya Tbk yang beralamat di Jl. Raya Pemda-Karadenan RT.04 RW.10 Kel. Karadenan Kec.Cibinong Kab.Bogor, Jawa Barat. bertujuan supaya pengelolaan barang pada gudang lebih efektif dan efisien dalam transaksi setiap barangnya. dengan menerapkan sistem komputerisasi maka sistem akan mengikuti perkembangan zaman yang makin modern, dimana segala sesuatu harus serba cepat dan tepat dalam segala hal, terutama pelayanan dalam keluar masuknya barang. dimana sistem pengelolaannya masih menggunakan sistem manual Microsoft Excel menjadi terprogram satu aplikasi. Dalam melakukan perancangan dan pembuatan aplikasi, penulis menggunakan metode observasi untuk mengamati dan meneliti masalah yang ada. Wawancara, yakni melakukan tanya jawab terhadap pihak terkait untuk memperoleh data yang lebih akurat, dan studi pustaka agar membantu memecahkan masalah yang ada. Hasil penelitian yang penulis lakukan dapat diperoleh dengan bentuk aplikasi fixed asset application untuk mengelola data barang, dan keluar masuknya barang untuk keperluan operasional toko Alfamart.
\end{abstract}

Kata Kunci: Asset, Inventori, Gudang, Sistem Informasi

\begin{abstract}
The author makes a fixed asset application system at PT Sumber Alfaria Trijaya Tbk which is located at Jl. Raya Pemda-Karadenan RT.04 RW.10 Kel. Karadenan Kec. Cibinong Kab. Bogor, West Java. aims to make the management of goods in the warehouse more effective and efficient in the transactions of each item. by implementing a computerized system, the system will follow the development of an increasingly modern era, where everything must be fast and precise in all things, especially services in the entry and exit of goods. where the management system still uses the Microsoft Excel manual system to be programmed into one application. In designing and making applications, the authors use the observation method to observe and examine existing problems. Interviews, namely conducting questions and answers to related parties to obtain more accurate data, and literature studies to help solve existing problems. The results of the research that the author did can be obtained in the form of a fixed asset application to manage goods data, and the entry and exit of goods for the operational needs of Alfamart stores.
\end{abstract}

Key Word: Asset, Inventory, Warehouse, Information System

\section{PENDAHULUAN}

Perkembangan teknologi sistem informasi di Indonesia pada ini berkembang sangat pesat hal ini dapat dilihat dari munculnya berbagai macam solusi teknologi informasi yang ditawarkan oleh pebisnis untuk memperoleh keuntungan baik secara material maupun nonmaterial. Penggunaan sistem informasi dilakukan karena memiliki beberapa kelebihan diantaranya untuk meningkatkan efektifitas, produktifitas, akses informasi yang sangat mudah dan mudah untuk dikembangkan.

PT Sumber Alfaria Trijaya Tbk membagi tugas dan tanggung jawab kepada masingmasing staf dalam suatu departmen. Sistem yang terdapat pada gudang GA saat ini masih menggunakan sistem manual. Proses pendataan keluar masuknya barang masih menggunakan Microsoft Excel sehingga penulis menilai bahwa sistem tersebut kurang efektif dan efisien. Pembuatan laporan bulanan pada departemen Fixed Asset juga masih menggunakan cara manual, dimana staf pengelola akan menginput data pada aplikasi pengolah data seperti Microsoft Excel. Pembuatan laporan dengan cara tersebut tentu akan ada kemungkinan kesalahan penulisan.

Menurut Menurut (Hartono, 2013), "Sistem informasi adalah kumpulan komponenkomponen yang saling berhubungan untuk bekerja mengumpulkan dan menyimpan data 
serta mengolahnya menjadi informasi untuk dipakai pada keperluan". Menurut (Kristanto, 2013), "Perancangan sistem adalah suatu fase dimana diperlukan suatu keahlian perancangan untuk elemenelemen komputer yang akan menggunakan sistem, yaitu pemilihan peralatan dan program komputer untuk sistem yang baru". Menurut (Subhan, 2012), "Sistem informasi adalah sistem yang dapat didefinisikan dengan mengumpulkan, memproses, menyimpan, menganalisis, dan mendistribusikan informasi untuk tujuan tertentu. Seperti sistem lainnya, sistem informasi adalah input, itu terdiri dari (data, instruksi) dan keluaran (laporan, perhitungan). Menurut (Warman, 2012), "Gudang adalah bangunan yang digunakan untuk menyimpan barang".

Menurut Hery (2012: 175), salah satu kelas aset yang dimiliki oleh perusahaan adalah aset tetap. Aktiva tetap ini merupakan bagian terpenting dari suatu bisnis dalam hal fungsi, investasi, dan pengawasan. Aset tetap dimasukkan ke dalam neraca dalam urutan tanah, bangunan, dan lainnya, dalam urutan masa manfaat terpanjang. Aset Tetap memiliki karakteristik dasar yang sama dengan aset lainnya, serta karakteristik tambahan yang membedakannya. Artinya, aset fisik yang dimiliki oleh bisnis untuk menghasilkan barang atau jasa sebagai bagian dari operasi normalnya. Pada akhir masa manfaatnya, harus dipinggirkan atau diperdagangkan, dan nilainya adalah kemampuan perusahaan untuk memperoleh hak legal atas aset-aset tersebut, yang semuanya bersifat non-tunai dan pada umumnya. Aset yang berasal dari jasa atau manfaat yang diterima dari aset tetap dengan jangka waktu satu tahun atau lebih.

Tujuan dari penelitian adalah membuat sistem informasi gudang PT Sumber Alfaria Trijaya Tbk yang dapat melakukan pengontrolan stok barang di gudang sehingga dapat memberitahukan tentang jumlah stok dan menyajikan pemrosesan data barang masuk dan data barang keluar dengan cepat dan akurat sehingga menghasilkan informasi yang sesuai kebutuhan

Manfaat dari penelitian ini di antaranya: (1) Perusahaan dapat menggunakan sistem informasi fixed asset application ini agar mampu meningkatkan kinerja pegawai khususnya di bagian gudang PT Sumber Alfaria Trijaya Tbk. (2) Mempermudah koordinasi pada internal PT Sumber Alfaria Trijaya Tbk terutama pada bagian gudang, supplier, dan toko Alfamart. Berdasarkan hasil pengamatan sementara dan kajian teori yang telah di susun oleh penulis, maka selanjutnya dapat dibangun kerangka berpikir tentang aplikasi sistem informasi fixed asset application.

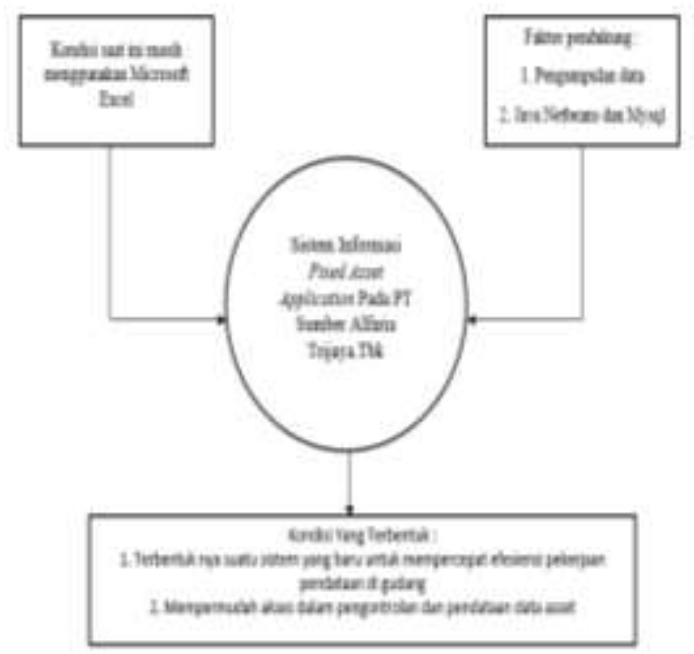

Gambar 1. Kerangka Berpikir

\section{METODE PENELITIAN}

Metode penelitian survei adalah metode ilmiah untuk mengumpulkan data untuk maksud dan tujuan tertentu. Dalam melakukan penelitian sebaiknya menentukan metode penelitian terlebih dahulu agar sesuai dengan penelitian yang diteliti. Metode investigasi kualitatif atau naturalistik adalah metode yang pada dasarnya, memiliki data yang dijelaskan secara wajar, atau memiliki sifat bahwa itu sendiri belum dimodifikasi oleh simbol atau angka. Sebuah studi kualitatif dapat didefinisikan sebagai serangkaian kegiatan atau proses yang bertujuan untuk mengumpulkan data atau informasi yang bersifat wajar terkait dengan aplikasi dalam hal aspek atau tujuannya. Metode Pengumpulan Data yang penulis lakukan, di antaranya :

Observasi: Pengumpulan data dilakukan dengan cara pengamatan langsung di tempat penelitian, yaitu pada PT Sumber Alfaria Trijaya Tbk. Peneliti mengamati secara langsung bagaimana proses gudang yang 
sedang berjalan sekaligus mengumpulkan data serta keterangan-keterangan yang akan digunakan dalam penelitian.

Wawancara: Wawancara yaitu teknik pengumpulan data dengan cara tanya jawab, dalam hal ini penulis melakukan wawancara dengan bertatap muka langsung. Namun, setelah adanya pandemi Corona Virus Disease19 (Covid-19) penulis melakukan wawancara melalui media telepon, layanan pesan singkat (WA) kepada staf karyawan departemen Fixed Asset terkait mengenai data yang berhubungan dengan judul yang telah ditentukan.

Penelitian kepustakaan: Metode pengumpulan data dalam penelitian kepustakaan adalah dengan mengumpulkan data dan informasi dari ekstrak buku dan beberapa hasil dari sumber lain yang relevan.

\section{HASIL DAN PEMBAHASAN}

Pada hasil pembahasan telah terbentuknya sebuah sistem yang dapat mengelola keluar dan masuknya asset pada departemen Fixed Asset PT Sumber Alfaria Trijaya Tbk dengan pembahasan detailnya sebagai berikut :

\section{Diagram Konteks Sistem Diusulkan}

Diagram konteks menampilkan keseluruhan sistem serta menggambarkan secara jelas. Pada entitas manager, manager tidak terlibat dalam pengelolaan aset. melainkan hanya menerima laporan akhir dari pemprosesan sistem yang dilakukan oleh staf.

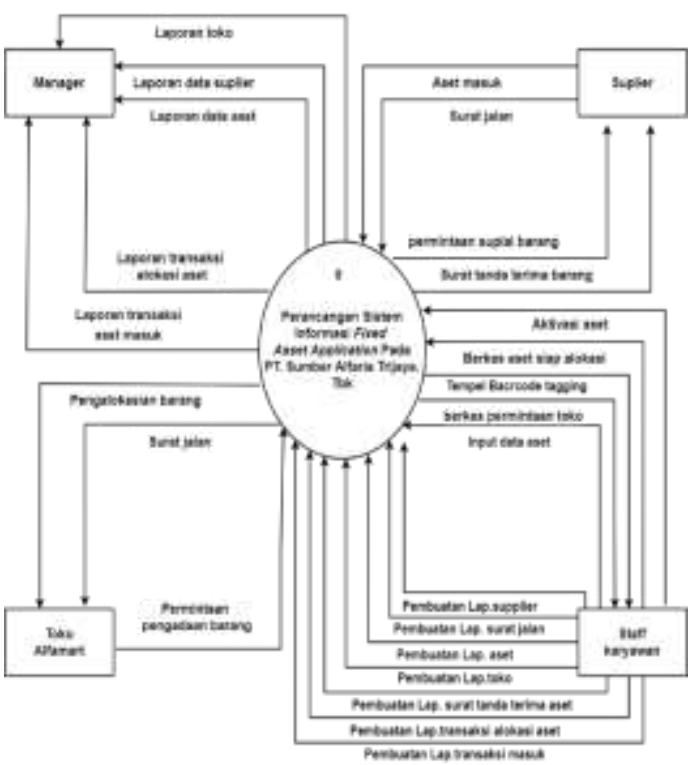

Gambar 2. Diagram Konteks

\section{Diagram Nol Sistem Diusulkan}

Diagram nol menampilkan penjabaran sistem serta menggambarkan secara detail dan jelas.

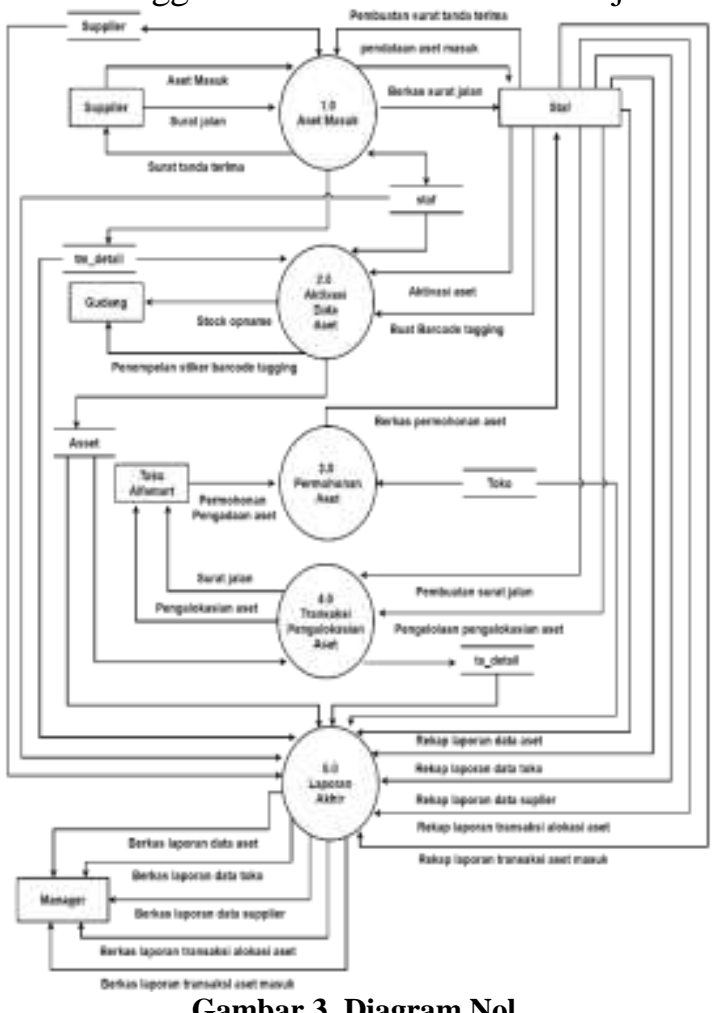

Gambar 3. Diagram Nol

\section{Entity Relatinship Diagram (ERD)}

Erd menampilkan susunan data yang disimpan dalam sistem secara abstrak dengan menggunakan notasi dan symbol

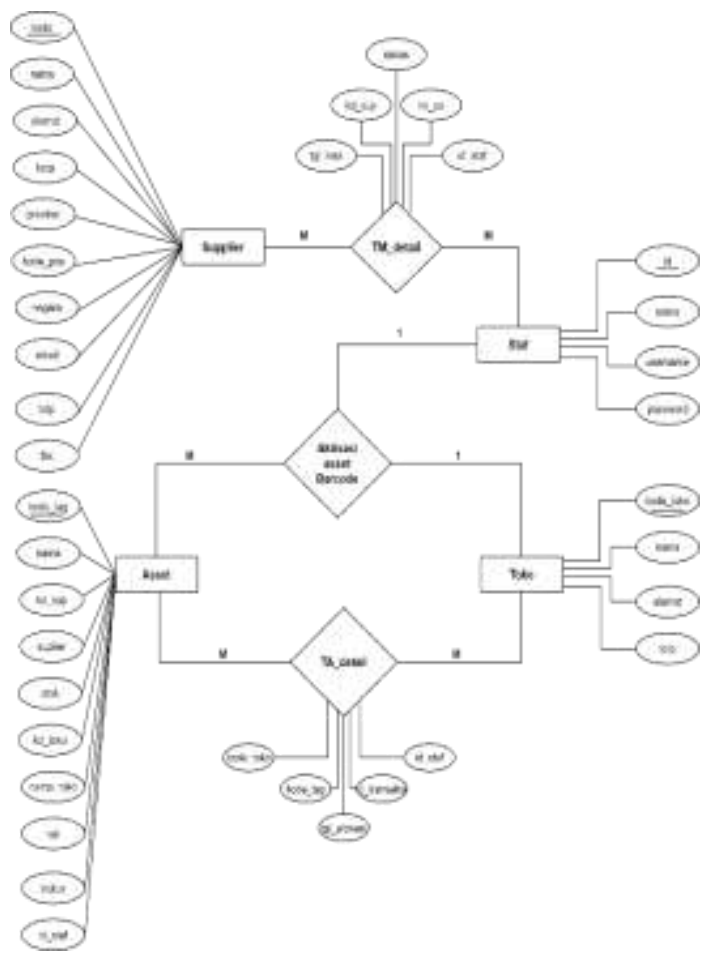

Gambar 4. Entity Relationship Diagram 


\section{Normalisasi Tahap Kedua (2NF)}

Hasil dari normalisasi adalah sebagai berikut :
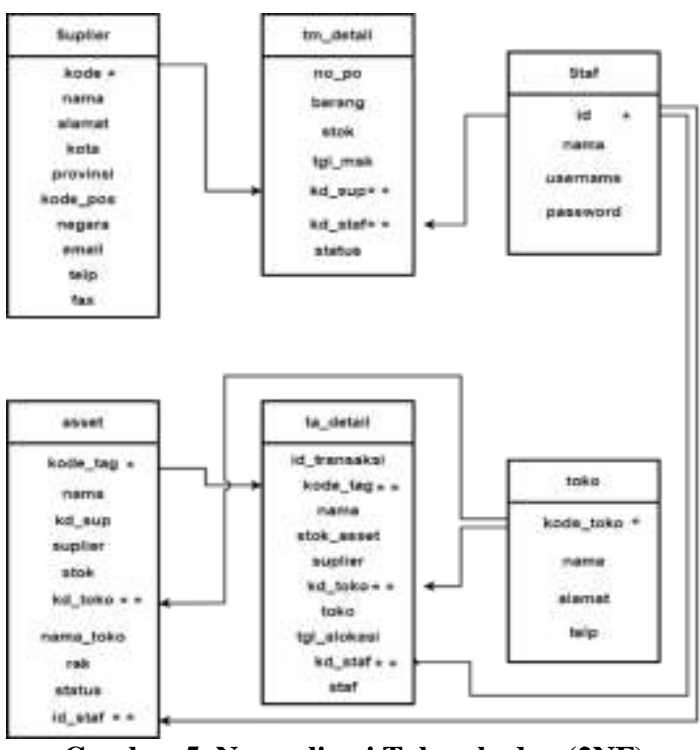

Gambar 5. Normalisasi Tahap kedua (2NF)

\section{Tampilan Menu Login}

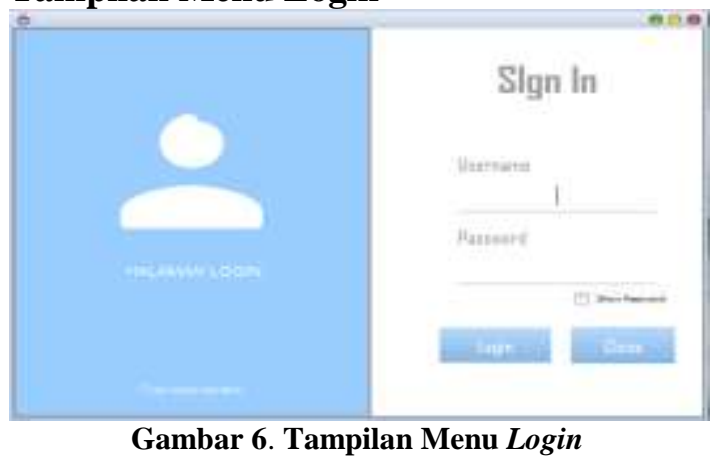

Form ini digunakan sebagai kunci sebelum staf masuk ke form-form lain nya, agar tidak semua orang yang dapat mengakses program ini. Sehingga dalam program ini kerahasiaan tetap terjaga dengan baik dan aman.

\section{Tampilan Menu Utama}

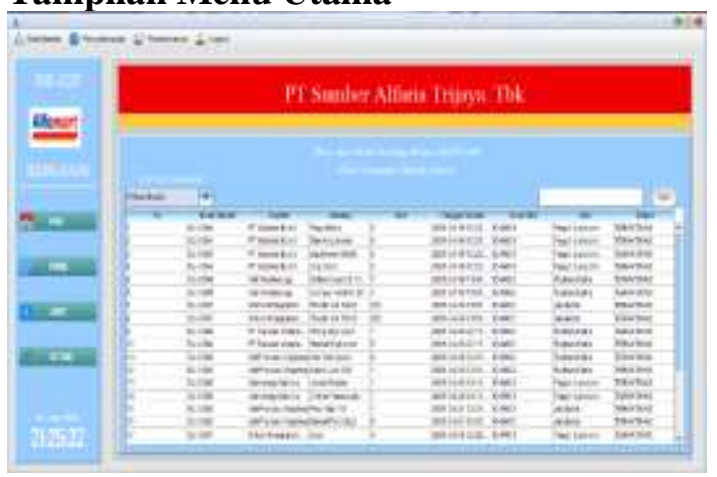

Gambar 7. Tampilan Menu Utama
Tampilan menu utama ini terdapat menu yang menampilkan form-form masukan dan keluaran. Menu data asset, data staf, data supplier, data toko, barang masuk dan alokasi asset merupakan form masukan. Sedangkan menu laporan merupakan form keluaran yang menampilkan laporan asset toko, supplier, laporan transaksi asset masuk, transaksi alokasi asset, surat tanda asset masuk, surat jalan.

Tampilan Form Transaksi Asset Masuk

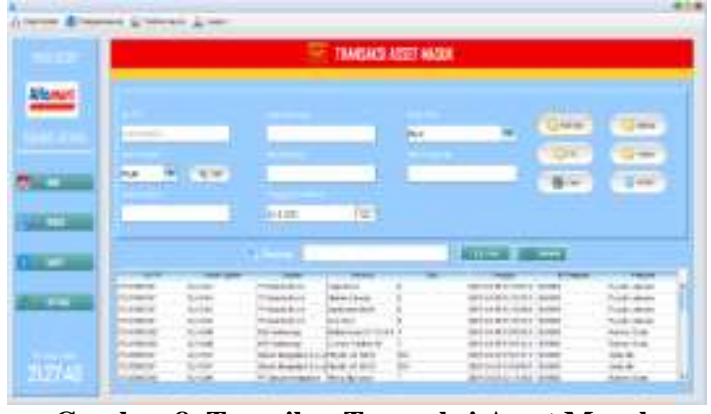

Gambar 8. Tampilan Transaksi Asset Masuk

Tampilan form transaksi yang berfungsi sebagai pendataan asset yang baru dikirim oleh supplier. Setelah pendataan asset akan di aktivasi untuk pendistribusian toko Alfamart tujuan.

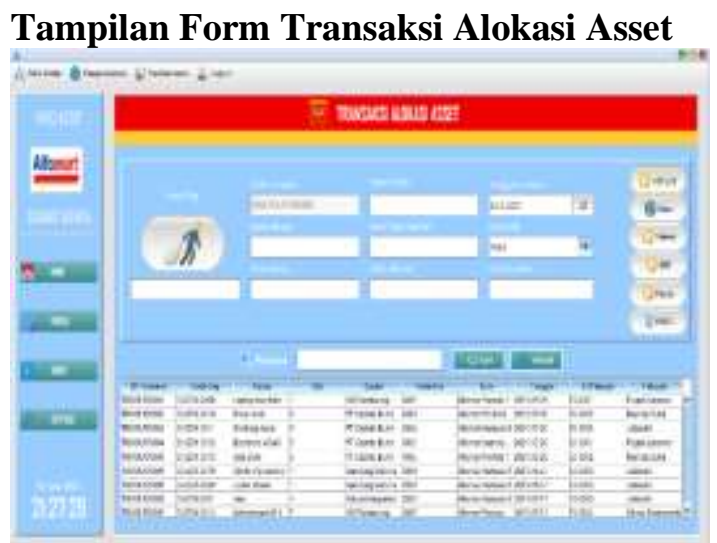

Gambar 9. Tampilan transaksi Alokasi Asset

Form transaksi alokasi asset berfungsi sebagai form yang mengelola data asset yang akan dialokasikan pada toko Alfamart tujuan. Setiap transaksi akan mendapatkan no kode transaksi tersendiri untuk mencirikan setaiap transaksi alokasi. Dengan form tersebut dapat otomatis membuat surat jalan untuk bukti pengiriman barang. 


\section{Tampilan Layar Laporan}

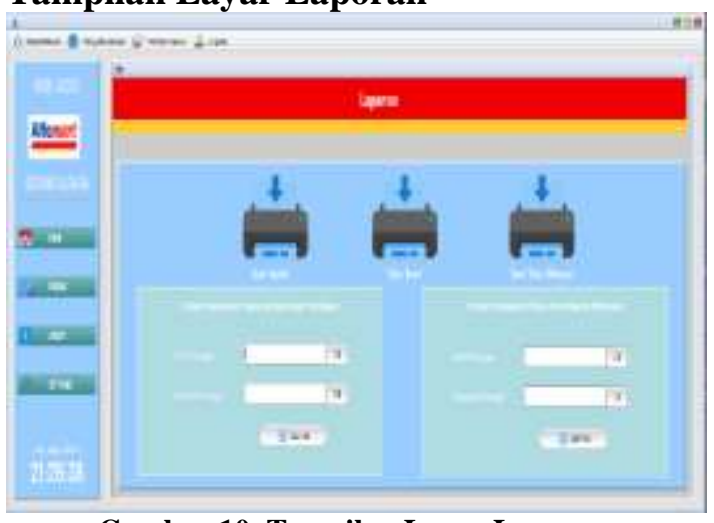

Gambar 10. Tampilan Layar Laporan

Pada form laporan ini digunakan sebagai tampilan layar untuk mencetak data-data yang diperlukan untuk kebutuhan laporan kepada manager setiap bulannya. Pada laporan ini terdapat laporan data diantaranya adalah laporan data asset, laporan data toko, laporan data supplier, laporan data transaksi asset masuk, laporan alokasi asset, surat tanda asset masuk, dan surat jalan.

\section{Tampilan Laporan Tanda Asset Masuk}

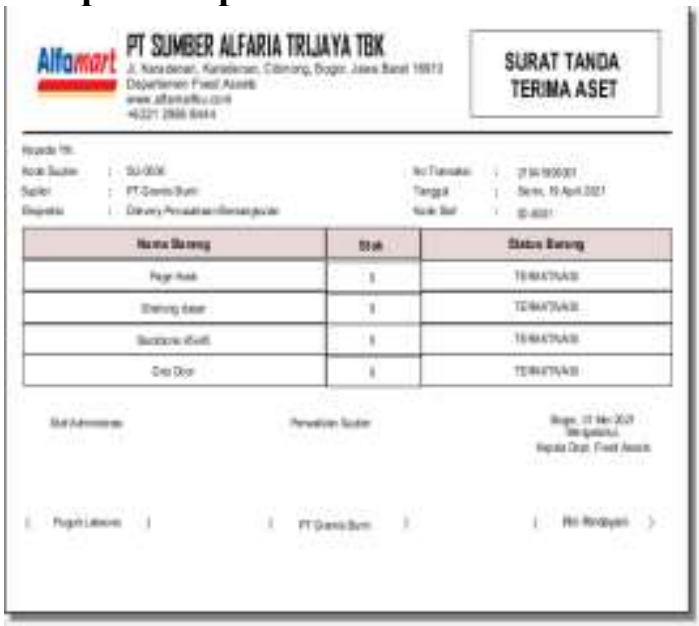

Gambar 11. Tampilan surat tanda asset masuk

berfungsi sebagai tanda asset yang telah di bongkar muat pada gudang telah terdata pada sistem dan pihak staf pengelola gudang memberikan surat tersebut sebagai tanda bukti asset diterima dengan baik.
Tampilan Laporan Surat Jalan

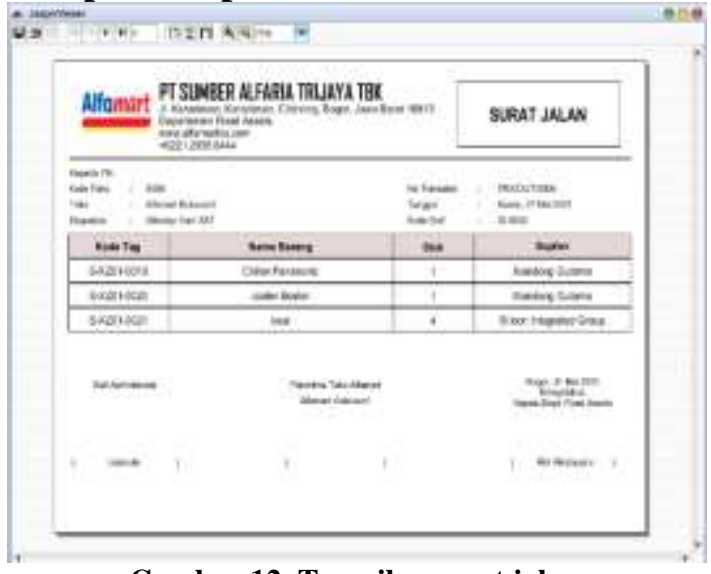

Gambar 12. Tampilan surat jalan

Laporan surat jalan ini digunakan untuk tanda bukti pengiriman barang pada toko Alfamart tujuan.

\section{SIMPULAN DAN SARAN}

Adapun simpulan yang dapat diambil dari“" Perancangan Sistem Informasi Fixed Asset Application Pada PT Sumber Alfaria Trijaya Tbk Berbasis Java Netbeans " dapat penulis simpulkan diantaranya : Telah terbentuknya program sistem informasi pengolahan data dengan memanfaatkan teknologi telekomunikasi yang berbasis java netbeans untuk dapat membantu kegiatan proses pengolahan asset pada gudang departemen fixed asset. Pencatatan data menjadi real time karena sudah terkoputerisasi. Pencarian data akan lebih cepat karena penyimpanan data sudah menggunakan database MySQL. Selain itu, peneliti sudah membuat fitur pencarian di dalam aplikasi sehingga staf hanya perlu mengetikkan data yang ingin dicari tanpa perlu mencarinya satu per satu dan takut datanya hilang. Hasil penelitian menunjukkan adanya sebuah sistem informasi pengolahan data berbasis java yang mempermudah staf pengelola dalam mengolah data keluar masuknya data asset dan Dengan menghasilkan laporan data asset, laporan data supplier, laporan data toko, surat jalan, surat tanda asset masuk, laporan transaksi asset masuk, dan laporan transaksi alokasi asset. 
Adapun saran yang dapat dikemukakan yaitu: Sistem informasi dapat dikembangkan lebih lanjut, sehingga informasi yang diberikan akan lebih jelas, lebih banyak, dan lebih lengkap agar dapat mengolah informasi dalam ruang lingkup yang lebih luas. Untuk menjaga kerahasiaan data-data yang ada, maka pada halaman login diberikan nama username dan kata sandi yang hanya diketahui oleh administrator perusahaan. Jika perlu ditambahkan fasilitas multiuser. Penulis berharap perancangan sistem informasi yang telah dibuat ini dapat dikembangkan lebih lanjut, seperti membuat sistem bersifat online agar lebih memaksimalkan pengecekan data asset secara real time tanpa perlu berada di lingkungan kantor PT Sumber Alfaria Trijaya Tbk.

\section{DAFTAR PUSTAKA}

Hartono, B. (2013). Sistem Informasi Manajemen berbasis Komputer (Edisi 1).RinekaCipta.http://library.fip.uny.ac. id/opac/index.php?p=show_detail\&id= 7600

Kristanto. (2013). Ekologi Industri (Ed. 1, Cet). Andi Offset.

Mohamad Subhan. (2012). Analisa Perancangan Sistem. Lentera Ilmu Cendikia.

Nurkuniana. (2011). Analisis Pernyataan Standar Akuntansi Keuangan (Psak) Nomor 16 Tahun 2011 Terhadap Akuntansi Aktiva Tetap Berwujud Pada Badan Penyelenggara Jaminan Sosial (Bpjs) Kesehatan Cabang Watampone. 2(16), 96-120. http://ojs.feb.uajm.ac.id

Warman,J. (2012). Manajemen Pergudangan. PT Puka Sinar Harapan. 